\title{
A CITY FOR THE NEXT GENERATION? INTRODUCTION TO THE 'KRAFT' COMPLEX SYSTEM OF INDICATORS IN CASE OF VESZPRÉM CITY WITH SPECIAL ATTENTION TO THE DIFFERENT AGE GROUPS OF LOCAL RESIDENTS
}

\author{
Mariann SZABÓ \\ anstitute of Advanced Studies Köszeg (Chernel street 14, 9730 Köszeg, Hungary), mariann.szabo@iask.hu
}

Cite this article: Szabó, M. (2019). A city for the next generation? Introduction to the 'KRAFT' Complex system of indicators in case of Veszprém city with special attention to the different age groups of local residents. Deturope. 11(3), 229-249.

\begin{abstract}
Nowadays we face the increasing significance of regions as social, cultural, political and economic interaction systems (Agnew, 2000, 2001 and Haukkala et al., 1999 in Palekiene, Simanaviciene, \& Bruneckiene, 2015). Due to the ongoing changes in global economy they face several challenges regarding the well-being of their inhabitants. Meanwhile, it is worth to consider that the different inhabitants and stakeholders would have different preferences for the development and use of various sources of the settlement. The differences in the utility functions may lead to conflicts. These conflict would arise among new comers and current land owners, businesses and NGOs or among inhabitants too, even among generation groups (like the case of "OK, Boomer"). As the economic concentrations attract increasing number of residents small and medium-sized towns (SMSTs) must design programs which improves their population retention. Challenging that, the KRAFT ('Creative City, Sustainable Region') Concept developed by iASK (Institute of Advanced Studies Kőszeg, Hungary) is a regional development initiative, which focuses on the connectivity and cooperation of key players. One of the major outcomes of the initiative is the 'KRAFT' complex system of indicators ('KRAFT-index'), an analytical tool suitable to demonstrate regional development tendencies regarding eight specific development areas (economic development, governance, social vitality, health, culture, networks, natural and built environment and education, learning). In 2017 we have conducted an on-site survey: during 2 months 1,200 questionnaires have been collected in Veszprém city. The computer-assisted data collection (filling one questionnaire required about 35-40 seconds) with the tracking ensure the representability checkable. The data collection aimed at identifying and collecting opinions and attitudes of local residents 16 years old and above, having permanent or temporary address in Veszprém. The sample is representative by age, gender and district (based on an integrated urban development strategy). The aim of the current research is to highlight differences in behavioural patterns and satisfaction among the generations which could be influential in the long-term development of the city which will be the European Capital of Culture 2023. The research results underline the significance of applying the generation theory into regional strategic planning, since dominant differences would be observed how the groups evaluate the environmental conditions, community cohesion of the city, as well as what environmental factors they evaluate as important and to what extent they are attached to the settlement.
\end{abstract}

Keywords: Sustainable cities and communities, small and medium-sized towns (SMSTs), regional development, 'KRAFT' complex system of indicators, generations

\section{INTRODUCTION}

Nowadays we face the increasing significance of regions as social, cultural, political and economic interaction systems (Agnew, 2000, 2001; Haukkala et al., 1999 as cited in Palekiene 
et al., 2015). The globalization and penetration of global supply chains forming new types of economic relations in regional systems (let just consider export-base theory of Douglas C. North, or The Growth Pole theory of Francois Perroux and Boudeville or The New Economic Geography by Paul Krugman for e.g.). By consequence, the research about how different territories would maximize the welfare of well-being of residents has become important. The economic - social - environmental resources, often referred as 'territorial' capital (Camagni \& Capello, 2013) is vital in case of any shocks which emerge in today's world of transitions like economic downturns, industry shocks which influence the path and pattern of regional economic growth, the quality of life of the inhabitants as well as the state of built and natural environment. Regions, with specific structures, often represents an inner core-periphery system, where the importance of cities, larger settlements is high, the neighbourhood often depends on the economic viability and growth of core areas (like urban-rural linkages). As the economic concentrations attract increasing number of residents small and medium-sized towns (SMSTs) must design programs which improves their population retention. (Miszlivetz \& Márkus, 2013)

Answering these challenges, the KRAFT ('Creative City, Sustainable Region') Concept developed by iASK (Institute of Advanced Studies Kőszeg, Hungary) is a regional development initiative, which focuses on the connectivity and cooperation of key players. By providing an integrated analytical framework that enables the collective recognition of individual (i.e., corporate, governmental, academic) and common interests, a more complex and profound understanding of middle- and long-term development objectives of dominant actors is sustained. This integrated approach is the key to future success and socio-economic and ecological sustainability (Miszlivetz \& Márkus, 2013).

One of the major outcomes of the initiative is the 'KRAFT' complex system of indicators, an analytical tool suitable to demonstrate regional development tendencies. In connection to the development initiative a survey has been implemented in Veszprém city in 2017.

There are different kind of shocks and stresses which influence the development path of cities, regions. For SMSTs a major stress is losing population, or in other terms the challenge for population retention. The generation group studies are gaining popularity nowadays from value assessment of the society to adaption to climate change. The concept is discussed in regional science too. The current study makes an attempt to demonstrate the relevance of generation theory for strategy elaboration of SMSTs. Hence the main research question is to what extent SMSTs could serve as an attractive place to live for younger generations? The current study gives a contribution to that discussion from the perspective of a Hungarian 
settlement, Veszprém aiming facilitating the research in that field in the future. Therefore, that study is composed as follows: on first hand provides theoretical background of role of cities in regional development, on second hand introduce the test area Veszprém city in brief. On third hand, at the methodological part the research framework is interpreted, introducing eight variables which have been assessed from generation groups' point of view concerning natural - social - economic - dimensions of the settlement with additional situation analysis and outcome indicators. After that, the results are highlighted concerning differences in behavioural patterns, value perception and satisfaction among the generation groups which could be influential in the long-term development of the city which will be the European Capital of Culture 2023.

\section{THEORETICAL BACKGROUND}

Considering the importance of cities in regional developments several attempts have been made in order to assess and make comparable the performance of cities in maximising human wealth or quality of life (QOL). The Quality of Life is the output of sustainable use of endogenous and exogenous factors implemented by regional/ urban development programs (Camagni \& Capello, 2013). For instance, The Urban Sustainability Index (USI) used by van Dijk and Mingshun (2005) measures the urban status, coordination, and potential of four Chinese cities, while the Urban Vitality Index (UVI) by Yang, Su, \& Chen (2010) emphasize the that urban ecosystems are parallel to vital organisms in terms of structure, function, performance and evolution, thereby the development status is the function of economic, social, natural and ecological regulatory subsystems respectively. Even national initiates exist like the Malaysian Urban Indicators Network as discussed by Marzukhi et al. (2011): sustainability city indicators can be seen as a measure that gives a summary of information about the subject of the problem. Applying system perspective too, the Winnipeg Quality of Life Indicators call the attention to human needs' compliance requirements, as Hardi and Pinter (2007) introduces the fundamental of the set of indicators in Winnipeg which aims to assess to what extent that people value QOL in the settlement; how they appreciate the size and pace of the city and its amenities; to what extent they are attached to their neighbourhoods; and whether they feel that Winnipeg is a great place to raise a family. There are other measures which aim at determining the inhabitants' QOL in a settlement. Mercer, an American leading provider of data on quality of living for employees sent to work abroad publishes each year a 'Quality of living city ranking' which 
evaluates the performance of nearly 500 global assignment destination (from Hungary Budapest is included) on recreation, housing, economic environment, consumer goods availability, public services and transport, political and social environment, natural environment, socio-cultural environment, school and education and finally, medical and health considerations (mobilityexchange.mercer.com, online). Another one, the 2018 edition of Arcadis' Sustainable Cities Index (SCI) explores city sustainability from the perspective of the citizen ranking 100 global cities (from Hungary Budapest is included in, too) on three pillars of sustainability: People - social, Planet - environmental and Profit - economic (Arcadis, online). The liveability survey by the Economist Intelligence Unit, what is the research and analysis division of The Economist Group simply assesses which locations around the world provide the best or the worst living conditions based on more than 30 qualitative and quantitative factors across five broad categories: stability, healthcare, culture and environment, education, and infrastructure (EIU, 2019). The free overview of the 2019 version lists the five biggest improvers as well as decliners, the ten most and least liveable cities worldwide. According to the 2019 version half of the most liveable cities are in Europe, from which Vienna is the first (EIU, 2019). As we can see, the most common indexes measuring QOL examine rather larger settlements, while we could find few ones which analyse SMSTs too (for e.g. the liveability assessment of CSR Hungary in 2012). The assessments/ indexes would be exploited as a policy instrument by which decision-makers would learn from other cases designing appropriate action series. Due to the developments of ICT sector, the demonstration of such measures could be implemented quite effectively. An example for that would be definitely the Cultural and Creative Cities Monitor of the European Union which second edition has been published in 2019 how well 190 cities in 30 European countries perform on a range of measures describing the 'Cultural Vibrancy', the 'Creative Economy' and the 'Enabling Environment' (compositeindicators.jrc.ec.europa.eu, online). The monitor uses five size category of settlements based on the number of inhabitants (XXL, XL, L, M, S). Six Hungarian are included in the 2019 version; one of them is Veszprém. Fundamentally, there are different types of indexes for evaluating the performance of cites from the perspective of different target groups. One branch, like the index of Arcadis or Mercer ranks cities from the attractiveness point of view in favour of the inhabitants, businesses, tourists and potential investors. The other major branch contributes to policy-development either on small-territorial scale (like Winnipeg Quality of Life Indicators) or on city networks (Cultural and Creative Cities Monitor of the European Union). The more one index is based on available, hard data from international databases the more replicable. 
Otherwise, by the combination of hard and soft indicators, not just the behavioural patterns would be examined, but the attitudes and motivations of inhabitants too, which is not covered by general data collections. The KRAFT system of indicators belong to the second category and aims to help policy and strategy development. In the current study, such measures will be discussed which concerns the QOL of inhabitants, more precisely the value perception of inhabitants on environmental factors; faith in other people, institutions; satisfaction with environmental conditions and he income situation of own households; as well as attitudes on attachment to the city and ambitions to live in the city on long run.

Regional development, aiming to maximize the welfare of inhabitants, to create a sustainable territorial structure for long term viability trough the mobilization and exploitation of local resources has high importance in population retention. Nevertheless, as while Simmie and Martin (2010) point out regional development is far from a smooth and incremental process, instead, it is the subject to all sorts of interruptions and disruptions (unexpected plant closures, unpredictable rise of major competitors, challenges arising from technological change and the like), and the state responses answering these challenges and the degree of decentralization and the adaptive capacity is different from territories to territories. Fekete (2018) for instance examines the economic development and governance pathway of a Hungarian regional centre underlying the importance of time dependent and evolutionary nature of urban systems' boost.

Increasing differences among regions and income inequalities within societies contributed to the increasing scientific interest concerning complex assessment of territories. Rácz, Koós \& Neumark (2006) examine social, economical relations of disadvantageous regions including employment patterns, income sources and income vulnerability, mobility trends, intergeneration mobility of the society, relational specialities role of weak and strong relations in humans' life, connectedness to various public and civil institutions and attractiveness of city, fidelity of inhabitants. Furthermore, answering the different needs of humans/ generation groups in urban development is an addressed issue by several studies. Barysheva and Kashchuk (2015) examining the impact of territorial marketing on improving the socio-emotional wellbeing of the older generation finds, that it is a useful tool creating and maintaining comfortable living conditions of different age groups, taking into considerations their characteristics, however it is a challenging issue whether generations should have their own area of activity and rest. Gébert, Bajmócy, and Málovics (2017) points out, while several study emphasize the importance of quality of life and liveable cities, in reality the core point of regional development is to operate and maintain the "urban growth machine" by Kirkpatrick \& Smith (2011). 
Challenging that, they suppose an "people-centred" analytical-evaluation approach based on the capability approach of Amartya Sen (1999).

Evidence both from the capability approach and Christaller's central place theory, that the size of the settlement determines high extent the development possibilities. Servillo, Atkinson \& Hamdouch (2017) introducing a Special Issue in Tijdschrift voor Economische en Sociale Geografie explains, that recently most attention has been paid to larger urban and metropolitan areas, within which smaller settlements are considered to constitute embedded settlement configurations largely 'subservient' to the metropolis. They emphasize, that the size issue that the terms themselves 'small and medium-sized towns (SMSTs)' carry is controversial: cities that are smaller than other cities imply the presence of a threshold that tends to become blurred when we observe a territory that has a wide variety of urban forms and different patterns of land use. Although, the importance of size (expressed by the number of inhabitants for e.g.) is inevitable, it is relative and moreover depends on the territorial context in which the urban settlement is located which varies from country to country. Their development is a function of macro and meso-trends affecting socio-economic dynamics of regional systems, in which the importance of capacity-building factors (both countable and uncountable) ascend. Kovács (2017) calls the attention too, to demographic changes to which urban strategies with special attention to cultural heritage exploitation could be a good perspective like in Kisújszállás. The examination of these capacity building factors often refers to the ecosystem services phenomena: La Rosa, Spyra, \& Inostroza, (2016) consider cultural values as vital source for development. Morvay (2017) underlines the importance of culture-based economy and calls the attention to the European Capital of Culture program. In addition to cultural development Shaw \& Kidd (2001) explains that, there is a growing appreciation that environmental considerations must be taken into account, balanced against and integrated into decision making processes particularly in relation to what might be considered the dominant forces of economic and social development.

\section{DATA AND METHODS}

Short description of the test area: Veszprém. Veszprém is one of the oldest urban areas in Hungary, a city with county rights. It is $15 \mathrm{~km}$ far from the Lake Balaton. The city with 56.000 (2018) residents is the administrative centre of the county of the same name. Veszprém is a historic town, a regional centre of the catholic church, a place, where the first institution of 
higher education was established in the country that taught the seven liberal arts as early as the $13^{\text {th }}$ century. The historic centre of Veszprém is the castle. The present-day historic town evolved during the town development constructions of the $18-19^{\text {th }}$ and the early $20^{\text {th }}$ century. World War II and the following period caused relatively little damage to the old centre. (veszprem.hu, online; www.veszpreminfo.hu, online; Örsi, Á., 1994)

Characteristics of the settlement. From population dynamics perspective Veszprém has become a significant centre after World War II, from the ' 50 s to the ' 90 s its population has been tripled (nepesseg.com, online). The population size was at maximum in 1990 when more than sixty-thousand inhabitants lived in the city. After that, the population size has been decreased. Parallel to the loss of the population the aging index of the settlement is continuously rising: in 2008 it was 151.7, while in 2017 it is 197.6 according to the Hungarian Central Statistical Office [HCSO], which is higher than the Hungarian average (178.4 in 2017). The decrease in the inhabitants' number is due to both the natural population loss and to the negative migration balance generally. The ratio of inhabitants has university degree according to the last population census in 2011 is $21.7 \%$, which is significantly higher than the Hungarian average (12.7\%). Veszprém has a diversified, strong local economy, the most important economic sectors are the machine, electrical, automotive, chemical, food, building, press and furniture industries, with the logistics sector also becoming more and more significant (investinveszprem.com, online). The preferable economic status is reflected by the income patterns: the brut net income per inhabitant is continuously increasing from 2009 and significantly higher than the Hungarian average. It may seem unreasonable that despite the stable economic performance of the city it has challenges with population retention. In relation to that the integrated urban development plan for the programming period between 2013 and 2020 discusses that new development programs aiming the introduction of higher-value added industries would improve the capacity (veszprem.hu, online). The strategy points out other challenges which mainly concern the traffic and poor travel conditions, conservation of natural resources, limited property of the local administration, maintenance and reconstruction of the built environment. From the viewpoint of introducing new type of economic development activities the fact that Veszprém won the title of the European Capital of Culture in 2023 has high importance. For the elaboration of the project, Veszprém applied jointly with the Bakony and Balaton Region for the ECC title, which will aim that culture and high added value creative industries would become the main motor of regional development (2023veszprem.hu, online). 
Data. The data collection aimed at identifying and collecting opinions and attitudes of local residents 16 years old and above, having permanent or temporary address in Veszprém. All respondents have been asked with the same questionnaire by the trained interviewers. In relation to the city survey 1,200 questionnaires have been collected. Computer-assisted data collection with tracking ensures the representability checkable. The sample is representative by age, gender and district. The questionnaire combines closed and open-ended questions. Closed questions concern both ordinal data (using 4-point Likert scale) and nominal data when different categories were restricted to a few options. In a few cases open questions were formulated in order to allow people to express what they think in their own words. Totally more than 60 questions have been asked in relation with economic development, governance, social vitality, health, culture, networks, natural and built environment and education, learning. Due to the collection of date of birth of all respondents, it is realizable to carry out the current research. From the wide range of questions, moreover hundreds of variables the study aims to analyse some aspects which are influential for urban development initiatives (based on reviewing the scientific literature interpreted) which are highly recommended to take into account concerning generation groups' in decision making processes.

Research themes and methods. At first, how the generation groups are distributed in districts is analysed. Next, the value perception of environmental factors and satisfaction level towards various elements of natural environment of generation groups is explained which provides comprehension to what kind of factors they consider most valuable in the city and how they evaluate current status and actions implemented for their conservation/maintenance. From long-term viability perspective it is crucial that the economic base of the city should provide favourable job opportunities for inhabitants and or generally the inhabitants would have enough income to live. Consequently, the assessment of satisfaction of with the income level of the household is discussed. The extent how inhabitants could rely on others in case of various difficulties have enormous impact on their well-being. Thus, this also part of the research how generation groups could expect help from different organizations/ groups in the city. The analysis provides information about the social connectedness of different age groups, too. Finally, two outcome indicators are discussed: first, to what extent are respondents attached to the city, secondly would they plan to live in the city on long run. Tab. 1 is about the themes, variables examined, scales (if relevant) and indicator applied in the analysis. The study uses basic statistical indexes, scales for analysis with the help of MS Excel Program. 
Table 1 Structure of the research

\begin{tabular}{|c|c|c|c|}
\hline Theme & Variable & Scale & Method/ indicator \\
\hline \multirow[t]{3}{*}{$\begin{array}{l}\text { General } \\
\text { information }\end{array}$} & $\begin{array}{l}\text { Respondents by } \\
\text { generation groups, sex }\end{array}$ & - & $\begin{array}{l}\text { Distribution of respondents by generation } \\
\text { groups, sex }(\%)\end{array}$ \\
\hline & \multirow{2}{*}{$\begin{array}{l}\text { Distribution of } \\
\text { respondents by } \\
\text { generation groups, } \\
\text { districts }\end{array}$} & - & $\begin{array}{l}\text { Share of inhabitants in the eight city districts } \\
(\%)\end{array}$ \\
\hline & & - & $\begin{array}{l}\text { Distribution of respondents by generation } \\
\text { groups in the eight districts }(\%)\end{array}$ \\
\hline \multirow[t]{2}{*}{$\begin{array}{l}\text { Natural } \\
\text { environment }\end{array}$} & $\begin{array}{l}\text { Value of environmental } \\
\text { factors }\end{array}$ & $\begin{array}{l}\text { 4-point } \\
\text { Likert } \\
\text { Scale }\end{array}$ & $\begin{array}{l}\text { Value perception in generation groups: } \\
\text { proportion of respondents } \\
\text { grading ' } 1 \text { ' and ' } 4 \text { ' } \\
\text { Most important natural environment } \\
\text { elements on generation groups' average } \\
\text { level }(\%)\end{array}$ \\
\hline & $\begin{array}{l}\text { Satisfaction with } \\
\text { environmental } \\
\text { conditions }\end{array}$ & $\begin{array}{l}\text { 4-point } \\
\text { Likert } \\
\text { Scale }\end{array}$ & $\begin{array}{l}\text { Proportion of satisfied respondents by } \\
\text { generation groups }(\%)\end{array}$ \\
\hline $\begin{array}{l}\text { Economic, } \\
\text { income } \\
\text { status }\end{array}$ & $\begin{array}{l}\text { Satisfaction level of } \\
\text { respondents concerning } \\
\text { the income situation of } \\
\text { own households }\end{array}$ & $\begin{array}{l}\text { 4-point } \\
\text { Likert } \\
\text { Scale }\end{array}$ & $\begin{array}{l}\text { Proportion of least and less satisfied } \\
\text { respondents to rather and absolute satisfied } \\
\text { by generation groups }(\%)\end{array}$ \\
\hline Society & $\begin{array}{l}\text { Help and support in } \\
\text { difficulties - faith in } \\
\text { other people, institutions }\end{array}$ & $\begin{array}{l}\text { 4-point } \\
\text { Likert } \\
\text { Scale }\end{array}$ & $\begin{array}{l}\text { Proportion of respondents by generation } \\
\text { groups to what extent they could rely on } \\
\text { others or except help at their surroundings in } \\
\text { case of various difficulties (ratio of strongly } \\
\text { disagree and disagree to agree and strongly } \\
\text { agree) }\end{array}$ \\
\hline \multirow[t]{2}{*}{ Outcomes } & Attachment to the city & $\begin{array}{l}\text { 4-point } \\
\text { Likert } \\
\text { Scale }\end{array}$ & $\begin{array}{l}\text { Proportion of respondents by generation } \\
\text { groups and categories (none, low, moderate, } \\
\text { high) }(\%)\end{array}$ \\
\hline & $\begin{array}{l}\text { Ambitions to live in the } \\
\text { city on long run }\end{array}$ & $\begin{array}{l}\text { 4-point } \\
\text { Likert } \\
\text { Scale }\end{array}$ & $\begin{array}{l}\text { Proportion of respondents by generation } \\
\text { groups who strongly disagree, agree and } \\
\text { strongly agree }(\%)\end{array}$ \\
\hline
\end{tabular}

Source: own compilation

As seen, the questionnaire uses 4-point Likert Scale questions for measuring, value, satisfaction, and agreement. Tab. 2 explains the values by categories.

Table 2 Value of 4-point Likert Scale questions

\begin{tabular}{|l|l|l|l|l|}
\hline Category & 1 & 2 & 3 & 4 \\
\hline Value & None & Low & Moderate & High \\
\hline Satisfaction & Least satisfied & Less satisfied & Rather satisfied & Absolute satisfied \\
\hline Agreement & Strongly Disagree & Disagree & Agree & Strongly Agree \\
\hline Importance & Not important & Less important & Important & Very important \\
\hline
\end{tabular}

Source: own compilation

It must be stated, that the analysis and results may have limitations on modelling the functioning and motivations of local societies. The analysis would carry out results for first exploration but 
in order to comprehend generation groups' role, their specific needs use of qualitative methods are highly recommended.

\section{RESULTS AND DISCUSSION}

In this section the results of the statistical analysis are interpreted according to the research framework.

\section{General information}

Among the respondents $46.75 \%$ is male, $5325 \%$ is female. For most of the generations male and female respondents are more or less evenly distributed, except the Baby boomers in which the number of female respondents are the double of males. (Tab. 3)

Table 3 Distribution of respondents by generation groups, sex (\%)

\begin{tabular}{|c|c|c|c|c|}
\hline \multirow{2}{*}{ Generation } & \multirow{2}{*}{ Definition } & Participants (\%) & \multicolumn{2}{|c|}{ Sex (\%) } \\
\cline { 4 - 5 } & -1946 & 6.08 & 46.58 & 53.42 \\
\hline Veterans & 31.42 & 37.14 & 62.86 \\
\hline $\begin{array}{c}\text { Baby boomers } \\
\text { (often referred in Hungary as } \\
\text { 'Ratkó Generation') }\end{array}$ & $1946-1964$ & & & \\
\hline Generation X & $1965-1979$ & 32.75 & 50.13 & 49.87 \\
\hline Generation Y & $1980-1994$ & 21.83 & 52.29 & 47.71 \\
\hline Generation Z & $1995-2010$ & 7.92 & 55.79 & 44.21 \\
\hline
\end{tabular}

Source: own compilation based on the results of the city survey in Veszprém city $(\mathrm{N}=1200), 2017$

In order to ensure representativeness, eight districts/ surroundings have been considered when construing the sample with the appropriate ratio of inhabitants as indicated:

1. 'Belváros', the city centre (8.58\%);

2. 'Dózsaváros', one of the oldest part of the settlement $(8.33 \%)$;

3. 'Iparváros', the industrial part (2.50\%);

4. 'Jeruzsálemhegy and Csatárhegy': Jerusalem Hill ('Jeruzsálemhegy') is a part with small streets and family homes while Csatár ( 'Csatárhegy') is a grape hill (4.58\%);

5. 'Egyetemváros', 'University town' part of the city with The University of Pannonia and its facilities (11.00\%);

6. 'Cholnokyváros', part of the settlement named after Jenő Cholnoky, a famous Hungarian geographer, hydrologist who was the member of Hungarian Academy of Sciences, born in Veszprém in 1870 (19.50\%);

7. 'Jutasi út menti lakóövezet', residential area along the Jutasi road dominated by housing estates built in the ' 70 s and ' 80 s (37.42\%);

8. and finally, 'Kádárta and Gyulafirátót', where detached houses dominate the landscape (8.08\%). (Csapó, Lenner 2012, veszprem.hu online) 
Csapó, and Lenner (2012) describing the settlement structure of Veszprém emphasize that horizontal plan of city clearly reflects its development path: how the structure of the fortressbased medieval town has been renewing including the involvement of the surrounding hills, development of the industrial zone. The structure also reflects the accelerating importance of preserving and maintaining urban green zones near to larger dwelling zones increasing the liveability of the city.

The more the population live in a certain district the more the probability for diversified generation portfolio, as we could observe from the results of the assessment of the city area composition by generations. Another effect on the diversification of the sample that the generation groups are unevenly distributed (as in reality) among the population, hence due to the size-effect larger segments are fragmented to higher extent than others. The next figure indicates how the population is distributed among the districts of the settlement, and furthermore how the population in those districts are diversified by generation groups.

Figure 1 Generation groups (\% of total population) by districts in Veszprém city

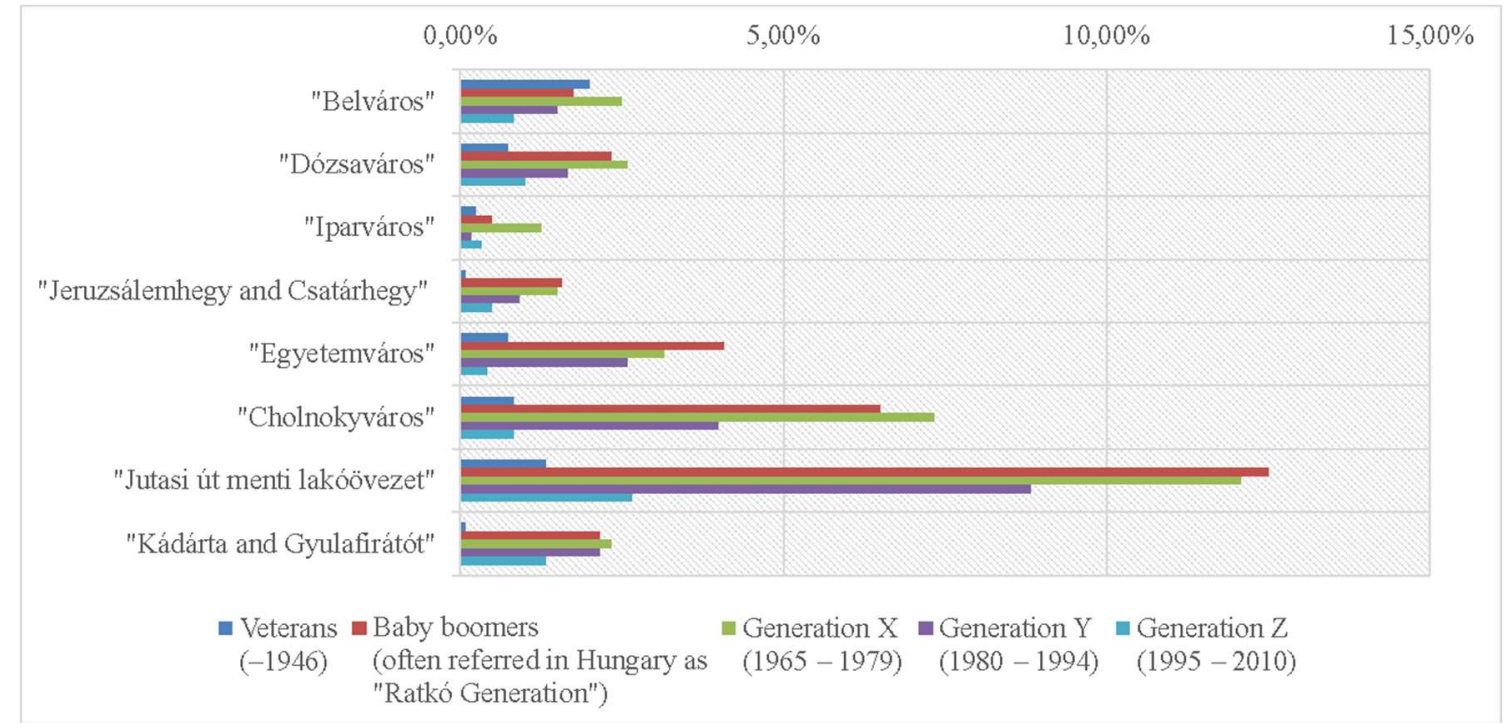

Source: own compilation based on the results of the city survey in Veszprém city $(\mathrm{N}=1200), 2017$

Summarizing the results: all generation groups appears in all city areas, so they are living together in specific mixed communities in neighbourhoods. The distribution of the inhabitants is uneven, since around $68 \%$ live in three districts: the university town, 'Cholnokváros' and the residential area along the Jutasi road. Four generations expect the Veterans live in with the highest share in the largest district, the residential area along the Jutasi road (37.42\%), while the highest ratio of the Veteran community lives in the city centre $(2.0 \%)$, where just the ratio of Generation X (2.50\%) is higher from the sample. Tab. 4 presents ranking values of how generation groups are distributed in districts (100\% per generation group). It would require deeper analysis assessing how the different generations would live together, but it seems that 
in case of the city centre, it is quite challenging that elder generations dominate it, while those parts of the city would be essential for younger ones to find the settlement 'viral'. It could be hardly managed that how the differences in the utility function in connection to usage could be addressed by urban development. The mixture of various purposes may cause conflicts among inhabitants (let's just consider the negative externalities of new business models for renting, or increasing noise level due to entertaining facilities).

Table 4 Generation groups' ranking in districts (2017)

\begin{tabular}{|c|c|c|c|c|c|c|}
\hline No. & Districts & Veterans & $\begin{array}{c}\text { Baby } \\
\text { boomers }\end{array}$ & $\begin{array}{c}\text { Generation } \\
\text { X }\end{array}$ & $\begin{array}{c}\text { Generation } \\
\text { Y }\end{array}$ & $\begin{array}{c}\text { Generation } \\
\text { Z }\end{array}$ \\
\hline 1. & 'Belváros' & 1. & 6. & 5. & 6. & 4. \\
\hline 2. & 'Dózsaváros' & 4. & 4. & 4. & 5. & 3. \\
\hline 3. & 'Iparváros' & 6. & 8. & 8. & 8. & 8. \\
\hline 4. & 'Jeruzsálemhegy and Csatárhegy' & 7. & 7. & 7. & 7. & 6. \\
\hline 5. & 'Egyetemváros' & 5. & 3. & 3. & 3. & 7. \\
\hline 6. & 'Cholnokyváros' & 3. & 2. & 2. & 2. & 5. \\
\hline 7. & 'Jutasi út menti lakóövezet' & 2. & 1. & 1. & 1. & 1. \\
\hline 8. & 'Kádárta and Gyulafirátót' & 8. & 5. & 6. & 4. & 2. \\
\hline
\end{tabular}

Source: own compilation based on the results of the city survey in Veszprém city $(\mathrm{N}=1200), 2017$

\section{Natural environment}

Inevitably influential part of quality of life of inhabitants in urban areas is the quality of natural environment. Respondents have been asked on one hand to name the value of various natural elements, on the other hand to explain their satisfaction towards environmental conditions. Tab. 5 introduce the elements of the analysis.

Table 5 Natural environment, factors

\begin{tabular}{|c|c|c|}
\hline First variable & Environmental factors, issues & Second variable \\
\hline \multirow{7}{*}{$\begin{array}{l}\text { Value of } \\
\text { environmental factors } \\
\text { (1: none, } 4: \text { high })\end{array}$} & Air quality of the settlement & \multirow{7}{*}{$\begin{array}{c}\text { Satisfaction with } \\
\text { environmental conditions } \\
\text { (1: Least satisfied, } 4: \\
\text { absolute satisfied) }\end{array}$} \\
\hline & Natural waters (lakes, rivers) & \\
\hline & Ground and groundwater & \\
\hline & Noise & \\
\hline & Waste, selective waste collection & \\
\hline & $\begin{array}{l}\text { Natural environment: protected areas, } \\
\text { woods, animal and plant species }\end{array}$ & \\
\hline & Cleanliness of the settlement & \\
\hline
\end{tabular}

Source: own compilation based on the results of the city survey in Veszprém city (N=1200), 2017

In case of the first variable, to investigate the value perception of generation groups the proportion of respondents grading ' 1 ' and ' 4 ' has been analysed. Tab. 6 indicates the share of those respondents who consider the different natural elements not important is low, often 
represent a small group of people, consequently strong conclusions could not be drawn, nevertheless it is quite positive result, that there are more topics which none of the respondents of Generation Z considers not important.

Table 6 Environmental factors and issues considered non-valuable by respondents (ratio of each generation groups, minimum and maximum values in bold)

\begin{tabular}{|c|c|c|c|c|c|}
\hline \multirow{2}{*}{ Environmental factors, issues } & \multicolumn{5}{|c|}{ Answers to 'none' by generation groups (\%) } \\
\cline { 2 - 6 } & Veterans & $\begin{array}{c}\text { Baby } \\
\text { boomers }\end{array}$ & $\begin{array}{c}\text { Generation } \\
\text { X }\end{array}$ & $\begin{array}{c}\text { Generation } \\
\text { Y }\end{array}$ & $\begin{array}{c}\text { Generation } \\
\text { Z }\end{array}$ \\
\hline Air quality of the settlement & $\mathbf{1 . 3 7}$ & 0.80 & 1.02 & 1.91 & 1.05 \\
\hline Natural waters (lakes, rivers) & $\mathbf{1 . 3 7}$ & 1.06 & $\mathbf{0 . 2 5}$ & 3.05 & $\mathbf{0}$ \\
\hline Ground and groundwater & $\mathbf{1 . 3 7}$ & 0.53 & $\mathbf{2 . 0 4}$ & 2.29 & $\mathbf{0}$ \\
\hline Noise & $\mathbf{1 . 3 7}$ & $\mathbf{2 . 3 9}$ & 1.53 & $\mathbf{4 . 5 8}$ & $\mathbf{3 . 1 6}$ \\
\hline Waste, selective waste collection & $\mathbf{1 . 3 7}$ & 1.06 & 1.78 & 1.53 & $\mathbf{0}$ \\
\hline $\begin{array}{c}\text { Natural environment: protected } \\
\text { areas, woods, animal and plant } \\
\text { species }\end{array}$ & $\mathbf{1 . 3 7}$ & $\mathbf{0 . 2 7}$ & 1.27 & 2.29 & $\mathbf{0}$ \\
\hline Cleanliness of the settlement & $\mathbf{1 . 3 7}$ & 0.53 & 1.78 & $\mathbf{1 . 1 5}$ & $\mathbf{0}$ \\
\hline
\end{tabular}

Source: own compilation based on the results of the city survey in Veszprém city ( $\mathrm{N}=1200), 2017$

More than $50 \%$ of all respondents of each generation groups declares that the listed factors/ issues have high value (Tab. 7). It is interesting that, on group level, in case of the younger generations the focus moves from result-type of elements (like cleanliness of the settlement or waste management) to natural capital equity (natural waters, protected areas, woods, animal and plant species).

Table 7 Environmental factors and issues considered highly valuable by respondents (ratio of each generation groups, minimum and maximum values in bold)

\begin{tabular}{|c|c|c|c|c|c|}
\hline \multirow{2}{*}{ Environmental factors, issues } & \multicolumn{5}{|c|}{ Answers to 'high' by generation groups (\%) } \\
\cline { 2 - 6 } & Veterans & $\begin{array}{c}\text { Baby } \\
\text { boomers }\end{array}$ & $\begin{array}{c}\text { Generation } \\
\text { X }\end{array}$ & $\begin{array}{c}\text { Generation } \\
\text { Y }\end{array}$ & $\begin{array}{c}\text { Generation } \\
\text { Z }\end{array}$ \\
\hline Air quality of the settlement & 67.12 & 63.13 & 63.36 & 56.49 & 69.47 \\
\hline Natural waters (lakes, rivers) & 64.38 & 61.80 & 63.10 & $\mathbf{5 9 . 1 6}$ & 67.37 \\
\hline Ground and groundwater & 67.12 & $\mathbf{6 4 . 4 6}$ & 61.58 & $\mathbf{5 9 . 1 6}$ & 67.37 \\
\hline Noise & $\mathbf{6 0 . 2 7}$ & $\mathbf{6 1 . 2 7}$ & 60.05 & $\mathbf{5 3 . 0 5}$ & $\mathbf{5 8 . 9 5}$ \\
\hline Waste, selective waste collection & 65.75 & $\mathbf{6 4 . 4 6}$ & 63.10 & 54.20 & 69.47 \\
\hline $\begin{array}{c}\text { Natural environment: protected } \\
\text { areas, woods, animal and plant } \\
\text { species }\end{array}$ & $\mathbf{6 8 . 4 9}$ & 63.13 & $\mathbf{6 1 . 0 7}$ & 55.34 & $\mathbf{7 2 . 6 3}$ \\
\hline Cleanliness of the settlement & $\mathbf{6 8 . 4 9}$ & 62.86 & $\mathbf{6 4 . 3 8}$ & 57.25 & 67.37 \\
\hline
\end{tabular}

Source: own compilation based on the results of the city survey in Veszprém city ( $N=1200), 2017$ 
Tab. 8 indicates the ranking of factors based on the value perception of generation groups. Besides the average, the standard deviation has been calculated to express the variability among groups.

Table 8 Most important natural environment elements on generation groups' average (\%)

\begin{tabular}{|c|c|c|c|}
\hline No. & Elements & Mean & $\begin{array}{c}\text { Standard } \\
\text { deviation }\end{array}$ \\
\hline 1. & $\begin{array}{c}\text { Natural environment protected } \\
\text { areas, woods, animal and plant } \\
\text { species }\end{array}$ & 64.13 & 6.69 \\
\hline 2. & Cleaniness of the settlement & 64.07 & 4.43 \\
\hline 3. & Ground and groundwater & 63.94 & 3,56 \\
\hline 4. & Air quality of the settlement & 63.91 & 4,93 \\
\hline 5. & Waste, selective waste collection & 63.40 & 5,66 \\
\hline 6. & Natural waters (lakes, rivers) & 63.16 & 3,04 \\
\hline 7. & Noise & 58.72 & 3,27 \\
\hline
\end{tabular}

Source: own compilation based on the results of the city survey in Veszprém city (N=1200), 2017

The other variable examined in relation to natural environment is the satisfaction with environmental conditions. As already mentioned, basically the respondents are satisfied with the state, availability, quality of the natural environment/ capital, considering that the proportion of answers for 3 or 4 (rather and absolutely satisfied) for each element is above $80 \%$ on average. Satisfaction with air quality of the settlement (85.51\%), natural environment: protected areas, woods, animal and plant species $(85.34 \%)$ and natural waters: lakes, rivers $(85.07 \%)$ has reached the highest portion on average. The average satisfaction level on one hand is the highest in case of Baby boomers $(86.40 \%)$ while the standard deviation is quite preferable $(2.16 \%)$, they are satisfied the most with the state of ground and groundwater and noise (in both case the proportion of answers for 3 and 4 is around $88 \%$ ), on the other hand is the lowest is the lowest in case of Generation Y (80.26\%), with the highest standard deviation among generation groups (3.48\%); they are less satisfied with air quality (79.01\%), state of ground and groundwater $(77.86 \%)$ and noise $(74.73 \%)$ on average. From the evaluated elements of the environment, the average satisfaction level of generation groups' standard deviation is the highest in case of noise level (5.13\%), air (3.96\%) and state of ground and groundwater (both 3.94\%) meaning that the generation groups' satisfaction level differs the most in case of these items. 


\section{Economic, income status}

For assessing the satisfaction level of respondents concerning the income situation of own households, they have been asked to evaluate the following statement: 'I am satisfied with the income level of my household'. Besides the four options one other option was provided for those who does not answer, cannot answer (do not know or not concerned). Around $91 \%$ of the residents made statement: $1.17 \%$ totally disagree, $11.17 \%$ disagree moderately, $38.00 \%$ agree and $40.58 \%$ strongly agree. The percent of inhabitants agrees with the statement is above $80 \%$ in 'Iparváros', 'Cholnokyváros' and 'Jutasi út menti lakóövezet'. They are followed by the 'Belváros', 'Jeruzsálemhegy és Csatárhegy', 'Egyetemváros', ‘Dózsaváros' and finally 'Kádárta és Gyulafirátót' where the proportion is still preferable, as it's above $50 \%$.

From the five generation groups Generation X and $\mathrm{Y}$ are the most satisfied followed by Baby boomers, then Veterans and finally Generation Z. In case of the last two the proportion of respondents who does not answer, cannot answer (do not know or not concerned) is relatively high compared to other generation groups which in case of Generation $\mathrm{Z}$ possibly due to the fact they are in dependent status.

Figure 2 Satisfaction with the income situation of the household of the generation groups

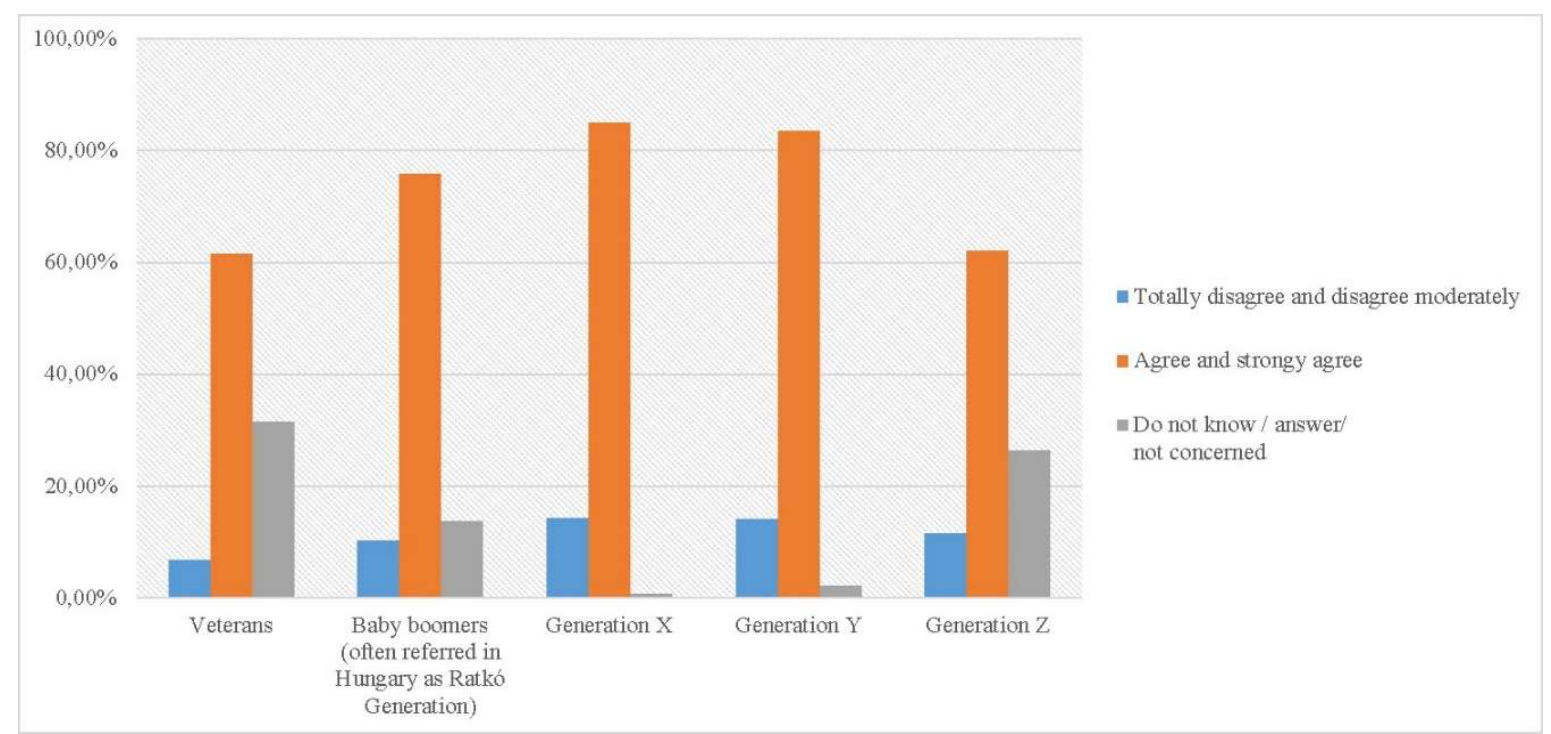

Source: own compilation based on the results of the city survey in Veszprém city $(\mathrm{N}=1200), 2017$

\section{Society}

Both strong and weak relations have emergent role in forming one's well-being. In the research we have asked respondents from whom they would expect help and support in difficulties, do they have faith in other people, institutions. Tab. 9 describes the research model. 
Table 9 Society - research model

\begin{tabular}{|c|c|c|c|}
\hline \multirow[t]{2}{*}{ Relations } & \multicolumn{3}{|c|}{ Type of difficulties } \\
\hline & Financial & Health & Psychical \\
\hline \multicolumn{4}{|l|}{ Family } \\
\hline \multicolumn{4}{|l|}{ Friends } \\
\hline $\begin{array}{llll}\begin{array}{l}\text { Neighbours, } \\
\text { surroundings }\end{array} & \text { people live in } \\
\end{array}$ & \multirow{2}{*}{\multicolumn{3}{|c|}{$\begin{array}{l}\text { Ratio of generations } \\
\text { - } \quad \text { strongly disagree and disagree; } \\
\text { - agree and strongly agree. }\end{array}$}} \\
\hline \multirow{2}{*}{\multicolumn{4}{|c|}{ - agree and strongly agree. }} \\
\hline & & & \\
\hline Church & & & \\
\hline
\end{tabular}

Source: own compilation

In case of any kind of difficulties the generations could expect help from family members. Concerning friendships, the differences are slightly higher: from generations to generations the level of reliance grows. Generally, respondents would rely more in family members, but in case of Generation $\mathrm{Y}$ and $\mathrm{Z}$ we can see in case of psychical difficulties, they prefer friends. Lesser extent, but neighbours, people live in surroundings are also important: around half of the generation groups agree and strongly agree they could expect help from them. The share of respondents who could rely on church in case of any kind of difficulty is moderate, from Baby boomers to Generation $\mathrm{Z}$ stands at the last place of examined relations/ institutions. Lesser extent than friends, but it worth to note, that in case of Generation $Y$ the respondents agree and strongly agree they could rely on colleagues is significantly higher than other generations.

Figure 3 From whom generation groups expect help? (Proportion of respondents agree and strongly agree)

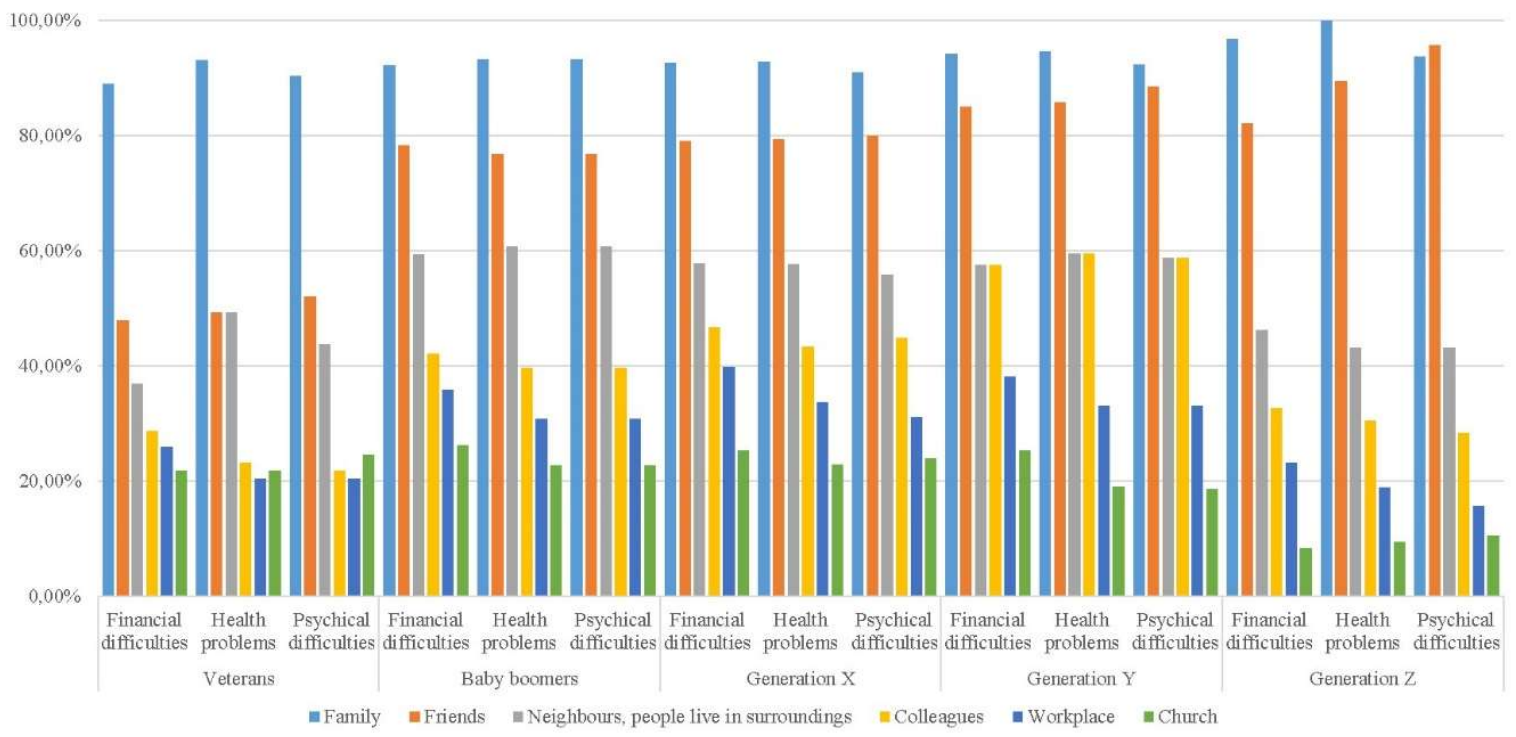

Source: own compilation based on the results of the city survey in Veszprém city $(\mathrm{N}=1200), 2017$ 


\section{Outcomes}

Attachment to the city and ambitions to live in the city on long run are the two variables from the range of outcome indicators which have been analysed currently. In case of the first variable, the distribution of respondents providing valid answer $(0.2 \%$ has not answered $)$ are: none (1.3\%), low (8.6\%), moderate (36.7\%) and high (63.2\%). As Fig. 4 indicates the level of attachment to the city is rather moderate and high among respondents. The proportion of respondents rating ' 4 ' is highest in case of the Veterans and shows diminishing tendency from generation groups to generation groups. The appropriate value in case of Generation $\mathrm{Z}(32.22 \%)$ is half of the Veterans' one $(65.28 \%)$.

Figure 4 Attachment to the city by generation groups

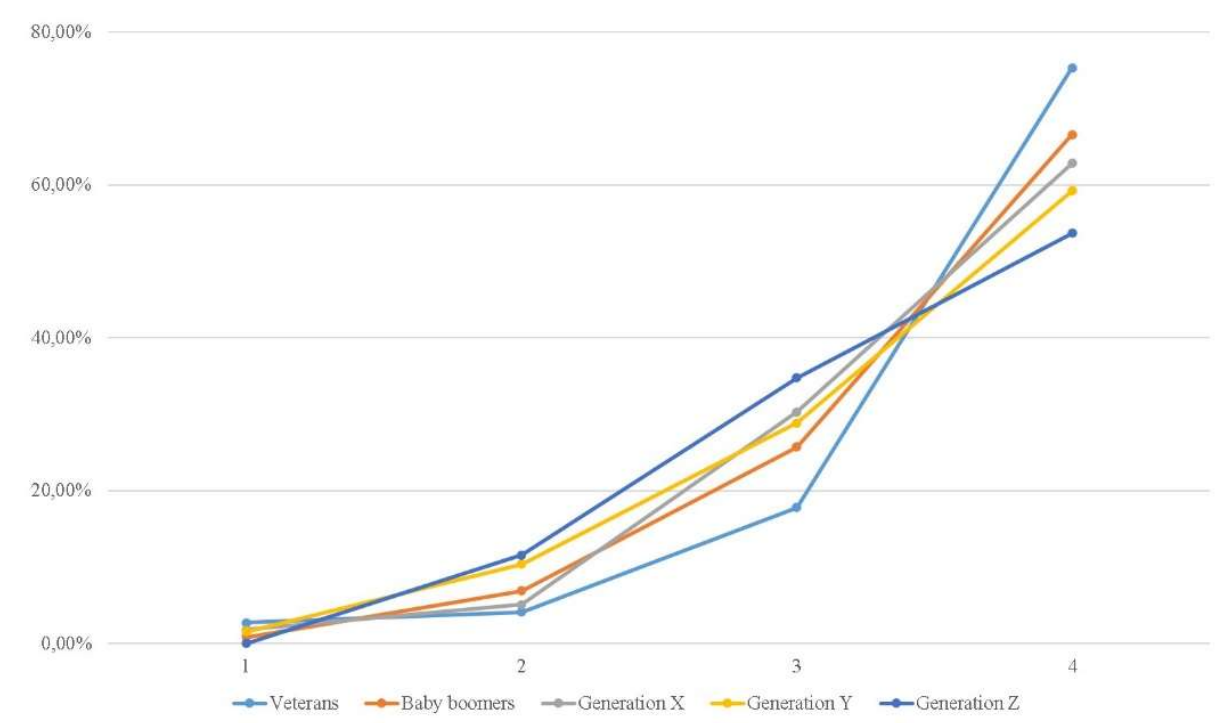

Source: own compilation based on the results of the city survey in Veszprém city $(\mathrm{N}=1200), 2017$

Last, ambitions to live in the city on long run is examined, which is one of the most important indicators for urban development, as it expresses the inhabitants' motivation being part of local community. According to Fig. 5 all generations would agree and agree strongly that they would live in the city on long run. Nevertheless, it is quite clear, that in case of Veterans, Baby boomers and Generation $\mathrm{X}$ the highest share of answers is achieved in case of option 'strongly agree' meanwhile, the local maximum of share is at 'agree' in case of Generation Y and Z meaning that the strength of willingness of younger generation groups' is lesser than 'elder generation', but still remarkable. 
Figure 5 Ambitions to live in the city on long run by generation groups

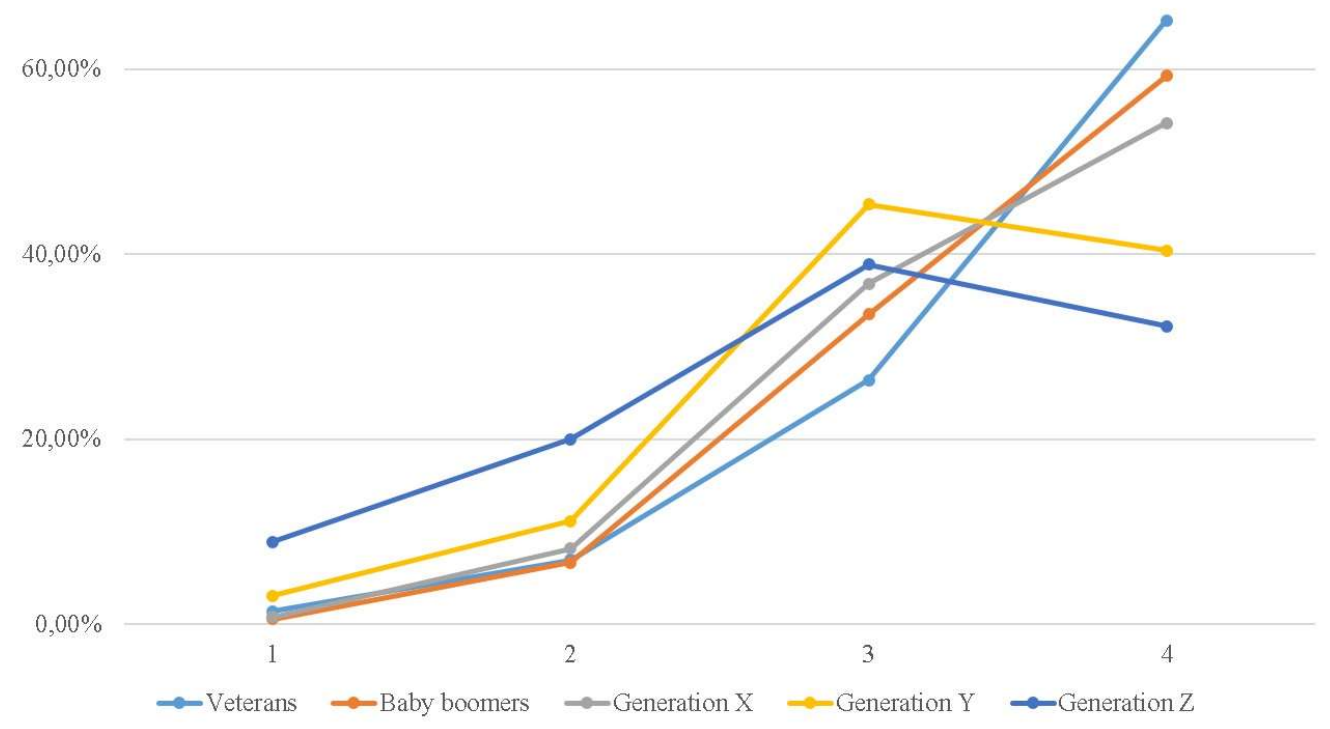

Source: own compilation based on the results of the city survey in Veszprém city $(\mathrm{N}=1200), 2017$

\section{CONCLUSION}

Current study considers regions as social, cultural, political and economic interaction systems which aims maximize the welfare of well-being of residents. In this process, economic - social - environmental resources, often referred as 'territorial' capital is vital, and the availability and accessibility as well as exploitation of these capital elements imply an inner core-periphery system, where the importance of cities, larger settlements is high, the neighbourhood often depends on the economic viability and growth of core areas. Recently most attention has been paid to larger urban and metropolitan areas, within which smaller settlements are considered to constitute embedded settlement configurations largely 'subservient' to the metropolis. Nevertheless, 'small and medium-sized towns (SMSTs)' are important in spatial structures from societal, economic and ecological point of view, or more holistically, from diversity perspective. Nowadays, the functioning of urban areas is more diverse than simply 'economic engines'. They are reliable for the exploitation of material and immaterial resource supply including population matters, income sources. Societal challenges, like income vulnerability, mobility trends, intergeneration mobility of the society, relational specialities role of weak and strong relations in humans' life, connectedness to various public and civil institutions and attractiveness of city, fidelity of inhabitants are requiring strategies enhancing long-term development. Programs, which aims to enhance well-being of cities should avoid consider population as a 'mass', rather creating and maintaining comfortable living conditions of 
different age groups, taking into considerations their characteristics, however it is a challenging issue whether generations should have their own area of activity and rest.

This study provides insights into a study which is consisted of the analysis of eight variables which have been assess from generation groups' point of view concerning natural - social economic - dimensions of the settlement and additional situation analysis and outcome indicators of Veszprém city. The elaborated analysis underlines that it is worth to take attention to special needs of generations in urban planning. The analysis has carried out that there are more environmental factors which younger generations consider important, which potentially could be the effect of 'climate crisis'. From the evaluated elements of the environment, the average satisfaction level of generation groups' standard deviation is the highest in case of noise level (5.13\%), air (3.96\%) and state of ground and groundwater (both 3.94\%) meaning that the generation groups' satisfaction level differs the most in case of these items - however the differences in the perception of the noise level would contribute to the less harmonized "together-living" of the generation groups. The generation groups' satisfaction with their income status is quite preferable, among the generations which have jobs currently it is higher than the others, meaning that the city would offer jobs with good salaries. From QOL perspective, an integrated community has high importance. The results show that the inhabitants have diverse relation structure and would expect help from others, nevertheless there are generational differences. The research has carried out that the level of attachment to the city is rather moderate and high among respondents, but the proportion of respondents rating ' 4 ' has a diminishing tendency from generation groups to generation groups. All generations would agree and agree strongly that they would live in the city on long run. Nevertheless, it is quite clear, that in case of Veterans, Baby boomers and Generation $\mathrm{X}$ the highest share of answers is achieved in case of option 'strongly agree' meanwhile, the local maximum of share is at 'agree' in case of Generation $\mathrm{Y}$ and $\mathrm{Z}$ meaning that the strength of willingness of younger generation groups' is lesser than 'elder generation', but still remarkable. From the results it is quite evident that inhabitants like to live in Veszprém and has strong connections to the settlement. The absence of those industries which attract and retain highly qualified population limits the attractiveness of the city, meanwhile the 2023 European Capital of Culture program and connecting regional development would be a large step forward.

\section{REFERENCES}

2023veszprem.hu (online). Veszprém - Balaton 2023 European Capital of Culture. Retrieved from: http://2023veszprem.hu/en/ecc-programme/ 
Arcadis (online). Citizen Centric Cities. The Sustainable Cities Index 2018. Retrieved from: https://www.arcadis.com/media/1/D/5/\%7B1D5AE7E2-A348-4B6E-B1D76D94FA7D7567\%7DSustainable_Cities_Index_2018_Arcadis.pdf

Barysheva, G., \& Kashchuk, I. (2015). Improving the socio-emotional well-being of the older generation through the implementation of territorial marketing. Procedia - Social and Behavioral Sciences, 166(2015), $62-68$.

Camagni, R. \& Capello, R. (2013). Regional Competitiveness and Territorial Capital: A Conceptual Approach and Empirical Evidence from the European Union, Regional Studies, 47(9), 1383-1402, DOI: 10.1080/00343404.2012.681640

Csapó, T., \& Lenner, T. (2012): Settlement Morphology of Veszprém. (In Hungarian Language). Geographical Review, 136(4), 439-452.

Gébert, J., Bajmócy, Z., \& Málovics, G. (2017). How to Evaluate Local Economic Development Projects from a People-Centred Perspective? An Analytical Framework Based on the Capability Approach. Deturope, 9(2), 4-24.

Hardi, P., \& Pintér, L. (2007). City of Winnipeg Quality-of-Life Indicators, in: Sirgy, M.J., Rahtz, D., Swain, D. (Eds.): Community Quality-of-Life Indicators: Best Cases II. Springer, pp.127-176

Hungarian Central Statistical Office [HCSO], online. Retrieved from: http://www.ksh.hu/?lang=en

Fekete, D. (2018). Economic Development and Economic Governance Through the Example of the City of Györ. Deturope, 10(1), 97-115.

investinveszprem.com (online). Economic sectors of Veszprém. Retrieved from: http://investinveszprem.com/eco

Kovács, T. (2017). Kisújszállás, 'the Cultural Capital of Great Cumania' - Shrinkage, Resilience and Culture-Based Urban Development in East Hungary. Deturope, 9(3), 122140.

La Rosa, D., Spyra, M., \& Inostroza, L. (2016). Indicators of Cultural Ecosystem Services for urban planning: A review. Ecological Indicators, 61(2016), 74-89.

Marzukhi, M. A., Omar, D., Leh, O. L.H., Hamir, M. S., \& Bargchi, M. (2011). Malaysian Urban Indicator Network: A Sustainable Development Initiative in Malaysia. European Journal of Social Science, 25, pp. 77-84.

Mercer (online). Quality of Living Ranking. Retrieved from: https://mobilityexchange.mercer.com/Insights/quality-of-living-rankings

Miszlivetz, F., \& Márkus, E. (2013). The KRAFT Index: Creative Cities - Sustainable Regions. Budapest Management Review, 44(9). 2-21.

Morvay, S. (2017). Cultural Ambitions of Cities in Central and Eastern Europe in the Light of Two Cities' - Tallin and Maribor - Case Studies. Deturope, 9(3), 162-176.

nepesseg.com (online). Retrieved from: http://nepesseg.com/veszprem/veszprem

Official website of Veszprém (online). Integrált Településfejlesztési Stratégia (Integrated urban development plan). Retrieved from: https://www.veszprem.hu/veszpremieknek/onkormanyzat/strategiak-programokkoncepciok/4489-integralt-telepuelesfejlesztesi-strategia

Official website of Veszprém (online). Veszprémi városrészek (districts of Veszprém). Retrieved from: http://www.veszprem.hu/veszpremieknek/kultura-mveszet/329veszpremi-varosreszek/5801-veszpremi-varosreszek

Örsi, Á. eds. (1994). Veszprém Guide. Private edition.

Palekiene, O., Simanaviciene, Z., \& Bruneckiene, J. (2015). The application of resilience concept in the regional development context. Procedia - Social and Behavioral Sciences, 2015(213), $179-184$. 
Rácz, K., Koós, B. \& Neumark, T. (2006): Social-Economical Relations of Disadvantageous Regions. (In Hungarian language). Space and Society, 20(2), p. 115-141.

Servillo, L., Atkinson, R., \& Hamdouch, A. (2017). Small and Medium-Sized Towns in Europe: Conceptual, Methodological and Policy Issues. Tijdschrift voor Economische en Sociale Geografie, 108(4), 365-379.

Shaw, D., \& Kidd, S. (2001): Sustainable development and environmental partnership at the regional scale: the case of Sustainability North West. European Environment, 11, 112 123.

Simmie, J., \& Martin, R. (2010). The economic resilience of regions: towards and evolutionary approach. Cambridge Journal of Regions, Economy and Society, 2010(3), 27-43.

The Economist Intelligence Unit [EIU] (2019). The Global Liveability Index 2019. A free overview.

Retrieved

from: http://www.eiu.com/public/thankyou_download.aspx?activity=download\&campaignid= liveability2019

Tourinform Veszprém (online). 5+1 reasons to visit Veszprém. Retrieved from: https://veszpreminfo.hu/record/5-1-reasons-to-visit-veszprem

van Dijk, M. P., \& Mingshun, Z. (2005). Sustainability indices as a tool for urban managers, evidence from four medium-sized Chinese cities. Environmental Impact Assessment Review, Vol. 25., 667-688.

Yang, Z., Su, M., \& Chen, B. (2010). Change of urban ecosystem development - A case study of Beijing, China. Procedia Environmental Sciences, Vol. 2., 681-688. 